УДК 323.15:271.4: 94(477.8) “1917/1921”

\title{
ЗАРУБІЖНА УКРАЇНІКА ПРО ДІЯЛЬНІСТЬ ГРЕКО-КАТОЛИЦЬКОЇ ЦЕРКВИ В ПЕРІОД ЗАХІДНО-УКРАЇНСЬКОЇ НАРОДНОЇ РЕСПУБЛІКИ
}

\author{
Наталія ЗЬОЛА \\ Державний вищий навчальний заклад \\ "Прикарпатський національний університет імені Василя Стефаника", \\ кафедра історіографії та джерелознавства, \\ вул. Шевченка, 57, 76018, Івано-Франківськ, Украӥна \\ e-mail:m.natal@ukr.net \\ DOI: 10.15330/gal.32.170-174 \\ ORCID: 0000-0002-0366-4895
}

\begin{abstract}
У статті висвітлюється відображення зарубіжною українікою діяльності Греко-католицької иеркви (ГКЦ) в суспільно-політичних подіях 1917-1921 рр. на західно-украӥнських землях. Здійснюється спроба висвітлити позииії активних діячів ЗУНР та УНР щзодо фактору релігї̈ в умовах революиії. Виділено особливе місие дослідженням ролі греко-католицького духовенства в партійно-політичній системі та зовнішній політиці ЗУНР. Розглядаються напраџювання сучасних діаспорних дослідників на рахунок етноконфесійних процесів. Враховуються матеріали, які ознайомлюють з місием ГКЦ у соціально-економічному та культурному вимірі ЗУНР.
\end{abstract}

Ключові слова: зарубіжна украӥніка, Греко-католицька церква (ГКЦ), Західно-Украӥнська Народна Республіка (ЗУНР).

На початку XX ст., в умовах суспільно-політичних трансформацій, Україна отримала шанс на відродження своєї державності. У результаті революційних подій 1917-1921 рр. відбулася консолідація нації та першочерговою була ідея утворення національної держави. Немаловажну роль в цьому процесі відіграла характерна ментальна риса галицьких українців, а саме - релігійність. У цей час беззаперечний авторитет і вплив на формування національної свідомості громадян мала Греко-католицька церква (ГКЦ). Церква не тільки духовно підтримувала організацію державного життя, а й активно включалася у роботу владних та військових структур новоутвореної у листопаді 1918 р. на теренах Західної України Західно-Української Народної Республіки (ЗУНР).

Вказана проблематика знайшла належне відображена в українській історіографії. Особливо варто приділити увагу опрацюванню робіт зарубіжних українських дослідників. У силу історичних обставин більшість документів періоду ЗУНР опинилася за межами України, тому об'єктивне дослідження національно-визвольних змагань 1918-1923 pp. у радянський період було неможливим. У таких умовах наукові напрацювання представників діаспори мають важливе значення для вивчення діяльності ГКЦ в період ЗУНР.

Після поділу України між більшовиками та поляками більша частина громадсько-політичних діячів Української народної республіки (УНР) та ЗУНР змушені були виїхати за кордон. Саме вони і заклали фундамент до вивчення проблеми. Емігранти об'єднувалися і створювали цілі центри у Відні, Мюнхені, Парижі. Вони засновували друковані органи - часописи, тижневики, журнали, газети для поширення своїх думок, ідей, напрацювань.

Варто звернути увагу на часопис "Тризуб”, який виходив у Парижі з 1925 р. Наприклад, березневий номер 1927 р. був розпочатий вступним словом про українську державність 1917-1918 pp. . Також у цьому ж номері О. Лотоцький аналізував питання релігійності української національно-демократичної революції 1917-1918 pp. ${ }^{2}$. До слова, тижневик політики та культури “Тризуб” був заснований з ініціативи Симона Петлюри та його соратників. I, віді-

\footnotetext{
${ }^{1}$ Весняні дні 1917 р. Тризуб. 1927. Ч. 1 2(70). С. 1-3. URL: http://diasporiana.org.ua/wp-content/uploads/ books/10380/file.pdf (дата звернення: 12.09.2018).

2 Лотоцький О. Г. Зневажена справа. Тризуб. 1927. Ч. 12 (70). С. 6-11.
} 
граючи вагому роль осередку УНР в еміграції, часопис відображав їхню позицію щодо розвитку подій 1919-1921рр. Тому слід обережно підходити до вивчення даних публікацій.

Український тижневик "Новий шлях"3 відзначає національну позицію Шептицького в українсько-польському протистоянні 1917 р. Автор обгрунтовував свою думку про дії митрополита щодо підтримки та розвитку української культури. У статті владика змальовується як покровитель українських традицій у ГКЦ ${ }^{4}$.

Для вивчення проблеми слід долучити матеріали тижневика суспільно-політичного та культурного життя - "Воля", ${ }^{\text {. }}$. Видання $є$ цінним джерелом інформації про боротьбу за українську незалежність та соборність України.

3-поміж доробку українського зарубіжжя варто розглянути праці духовних істориків o. I. Нагаєвського ${ }^{7}$, о. В. Лаби ${ }^{8}$. Вони брали активну участь у громадсько-політичному житті ЗУНР та були капеланами УГА. Дані фактори й відобразились у спогадах священників 9,10 .

Варте уваги спеціалізоване видання ${ }^{11}$ громадсько-політичної постаті о. I. Сохоцького. Історик присвятив своє дослідження питанню: “Що дала ГКЦ українському народові?”. Він розглядав такі маловивчені питання як робота духовенства у царині науки, освіти та культури. Частково роль духовенства у період 1918-1923 рр. на західноукраїнських землях висвітлюють праці діячів ЗУНР - К. Левицького ${ }^{12}$, О. Назарука ${ }^{13}$, I. Макуха ${ }^{14}$.

Наприклад, хорунжий Д. Микитюк видав п'ять томів джерельних матеріалів до історії Української Галицької Армії (УГА) ${ }^{15}$. У своїй праці дослідник розкривав організацію та значення інституту капеланства в УГА ${ }^{16}$. Військовий діяч перераховував імена душпастирів, які брали безпосередню участь у подіях Листопадового зриву ${ }^{17}$. Також Д. Микитюк показав роль греко-католицького духовенства у динаміці організації влади на місцях. На думку, ГКЦ в повній мірі виконала свій обов'язок перед народом ${ }^{18}$.

Галицький політик I. Макух також у своїй роботі зауважував, що греко-католицьке духовенство активно працювало на побудову держави та тї оборони ${ }^{19}$.

Громадсько-політичні діячі УНР висвітлюють епоху української національно-демократичної революції 1917-1921рp., і частково роль у ній ГКЦ. Так, до вивчення проблеми варто долучити праці В. Винниченка ${ }^{20}$, Д. Дорошенка ${ }^{21}$, П. Скоропадського ${ }^{22}$ та Є. Коновальця ${ }^{23}$. При цьому, необхідно звернути увагу на фактор суб'єктивності робіт.

\footnotetext{
${ }^{3}$ Митрополит Шептицький - покровитель української культури. Новий Шлях. 1944 р. Ч. 26. URL: http://tsdazu.gov.ua /index.php/ua/online /47-all/1262-200218.html (дата звернення: 15.09.2018).

4 Там само.

5 Лотоцький О. Г. Брат на брата. Воля. 1921. Т. 2. С. 210-217.

${ }^{6}$ Чижевський П. І. Основи української державності. Воля. 1921. Т. 2. С. 404-418.

${ }^{7}$ Нагаєвський І. Д. Спогади польового духовника. Торонто, 1985. 185 с.

${ }^{8}$ Лаба В. Митрополит Андрей Шептицький. Люблін, 1990. 63 с.

${ }^{9}$ Нагаєвський І. Д. Спогади польового духовника....

10 Лаба В. Митрополит....

${ }^{11}$ Сохоцький І. Й. Що дали Греко-Католицька Церква та її духовенство Українському Народові. Філадельфія, 1953. 103 с.

12 Левицький К. А. Великий зрив. Нью-Йорк, 1968. 151 с.

${ }^{13}$ Назарук О. Т. Рік на Великій Україні. Відень, 1920. 344 с.

${ }^{14}$ Макух I. І. На народній службі. Детройт, 1958. 628 с.

${ }^{15}$ Микитюк Д. Українська Галицька Армія. Т. І. Вінніпег, 1958. 673 с.

16 Так само. С. 311-312.

${ }^{17}$ Так само. С. 307.

${ }^{18}$ Так само. С. 310.

${ }^{19}$ Макух I. І. На народній службі... С. 231.

${ }^{20}$ Винниченко В. К. Відродження нації (Історія української революції, кінець 1917 р. - грудень 1919 р.) : в 3-х частинах. Ч. 3. Київ ; Відень, 1920. 535 с.

${ }^{21}$ Дорошенко Д. І. Історія України 1917-1923 рр. Нью-Йорк, 1954. Т. 2.512 с.

22 Скоропадський П. П. Спогади. Кінець 1917 - грудень 1918. Київ ; Філадельфія, 1995. 493 с.

${ }^{23}$ Коновалець С. М. Причинки до історії української революції. Прага, 1928. 38 с.
} 
Зокрема, В. Винниченко у своїх спогадах проаналізував структуру діячів ЗУНР. Письменник намагався довести, що за своєю морфологією галицька еліта не була революційною i, здебільшого, заглиблювалась у паперову та парламентську роботу ${ }^{24}$. I це, на думку дослідника, було результатом того, що інтелігенція, в основному, була вихідцями з кола сільської буржуазії та священицьких родин ${ }^{25}$.

У 70-х роках Л. Шанковський у своєму дослідженні ${ }^{26}$, яке й базувалося на працях Д. Микитюка висвітлював роль духовенства в УГА. Автор переконував, що армію очолила інтелігенція, а саме вихідці $з$ родин греко-католицького духовенства. Тому завдяки цьому, на думку Л. Шанковського, збройні сили ЗУНР складались з національно-патріотично свідомих військових. Обгрунтовуючи дану тезу, історик спростовував польські твердження про “темного хлопа", який не усвідомлював за що воював у $1918-1921$ pp. ${ }^{27}$.

Дослідник I. Сохоцький (псевдонімом Сидір Ярославин) писав, що представники ГКЦ стояли біля витоків державного будівництва $3 \mathrm{HP}^{28}$. Так, автор відзначає, що еліта українського народу входила до Української конституанти. I серед цих найкращих людей, за словами громадсько-політичного діяча, високий відсоток духовенства ${ }^{29}$.

Праця історика Г. Лужницького "Українська Церква між Сходом і Заходом" "з0 присвячена важкому історичному шляхові Української Церкви, яка через геополітичні обставини змушена була вибирати між Заходом і Сходом - Римом і Царгородом - Варшавою і Москвою, i, врешті, стала розірваною між ними. Дослідник приділяв увагу унійній акції ГКЦ, а саме апостольським візитам Владики до Канади, Бразилії та Аргентини 1921-1923 pp. Саме під час цих подорожей А. Шептицький шукав підтримки для західної України.

Також Г. Лужницький виділяв титанічну роботу греко-католицького духовенства. Мова йде про заснування величезної кількості католицьких товариств (Марійське товариство молоді) та організацій, підготовка релігійної літератури та преси, розквіт чернечих чинів (Студитський Чин). Автор вважав, що така плідна праця ГКЦ сприяла вихованню пастви, в основному молоді, у релігійно-моральному дусі.

Автор Н. Чиж наголошувала не тільки на підтримці митрополитом створення ЗУНР, а й на захисті ії подальшої долі після Ризького договору. Дослідниця виокремила факт переговорів між Шептицьким та представниками Антанти. На яких митрополит протестував проти приєднання Східної Галичини до Польщі. Не менш важливим є наведений автором факт пошуку Шептицьким фінансово-матеріальної підтримки для зруйнованих війною західноукраїнських земель ${ }^{31}$.

Таким чином, безперечно діаспора внесла значний внесок у дослідження діяльності ГКЦ у період ЗУНР. На початку ХХ ст. саме дослідники українського зарубіжжя $є$ науковцями 3 одного боку, а з іншого - священиками, громадськими та політичними діячами, тобто свідками епохи. Це дає можливість відобразити дану проблему з середини. При цьому слід ураховувати фактор суб'єктивності авторів. Адже дуже часто діячі у своїх працях намагались виправдати свої прорахунки у боротьбі за державність. Проте потрібно відзначити вагомий внесок представників еміграції у дослідження ролі ГКЦ, які зуміли накопичити низку джерельного та статистичного матеріалу, завдяки чому ми отримали грунтовну базу для вивчення ролі духовенства в політичних подіях 1917-1921рр. Молода генерація діаспорних дослідників не обмежується вивченням позиції ГКЦ в державотворенні ЗУНР. Вона взялась за опрацювання мало-

\footnotetext{
${ }^{24}$ Винниченко В. К. Відродження нації... С. 395-396.

${ }^{25}$ Так само. С. 395.

${ }^{26}$ Шанковський Л. П. Українська Галицька Армія: воєнно-історична студія. Вінніпег, 1974. 396 с.

${ }^{27}$ Так само. С. 88.

${ }^{28}$ Ярославин С. Визвольна боротьба на західно-українських землях 1918-1923 рр. Філадельфія, 1956. $183 \mathrm{c.}$

29 Ярославин С. Визвольна боротьба... С. 81-82.

30 Лужницький Г. Л. Українська церква між Сходом і Заходом: нарис історії Української Церкви. Філадельфія : Провидіння, 1954. 723 с.

${ }^{31}$ Чиж Н. Коли покликання стає життям. Шлях перемоги. № 31.3 серпня 2005 р. (2669). URL: http://tsdazu.gov.ua/ index.php /ua/online/47-all/1262-200218.html (дата звернення: 10.10.2018).
} 
відомих сторін діяльності духовенства у соціально-економічній та культурній сфері і, при цьому, відзначає авторитетність митрополита Андрея Шептицького та його внесок у розвиток ЗУНР.

\title{
FOREIGN UKRAINIAN ON THE ACTIVITY OF GRECO-CATHOLIC CHURCH IN THE PERIOD OF THE WESTERN UKRAINIAN PEOPLE'S REPUBLIC
}

\author{
Natalia ZOLA \\ State Higher Educational Institution \\ "Vasyl Stefanyk Precarpathian National University", \\ Department of Historiography and Source Studies \\ Shevchenko St., 57, 76018, Ivano-Frankivsk, Ukraine, \\ e-mail:m.natal@ukr.net
}

\begin{abstract}
Summary
The article highlights the reflection by the foreign Ukraine of the activities of the Greek Catholic Church (HCC) in the socio-political events of 1917-1921 on the western Ukrainian lands. An attempt is being made to highlight the positions of active figures of the ZUNR and the UPR on the factor of religion in the conditions of revolution. A special place is dedicated to the study of the role of the Greek-Catholic clergy in the party-political system and foreign policy of the ZUNR. The work of modern diaspora researchers on the account of ethnoconfessional processes is considered. Included are materials that familiarize with the place of the SCC in the socio-economic and cultural dimensions of the ZUNR.

In November 1918, the Western Ukrainian People's Republic (ZUNR) was formed on the territory of Western Ukraine. The church not only spiritually supported the organization of public life. The clergy were actively involved in the work of the authorities and military structures of the newly formed state. This topic has been properly reflected in Ukrainian historiography. Especially worthy of attention is foreign Ukrainian. Due to historical circumstances, most documents of the ZUNR period found themselves outside of Ukraine. And an objective study of the national liberation struggles of 1918-1923 in Soviet Ukraine was not possible. In such conditions, the work of the diaspora is essential for the study of the activities of the GCP during the ZUNR.

Undoubtedly the diaspora has made a significant contribution to the research of the CCC during the ZUNR. At the beginning of the twentieth century. it is the researchers of foreign countries that are scientists on the one hand, and on the other - priests, public and political figures, that is, witnesses of the era. This makes it possible to reflect this problem from the middle. It should take into account the factor of subjectivity of the author. However, emigration in this period has accumulated a lot of source and statistical material. The young generation of diaspora researchers is not limited to studying the role of SCC in the creation of the ZUNR. She embarked on working out the little-known parties of the clergy in the socio-economic and cultural sphere.
\end{abstract} $(Z U N R)$.

Keywords: foreign Ukrainian, Greek Catholic Church (CCC), Western Ukrainian People's Republic

\section{REFERENCES}

Doroshenko D. I. Istoriia Ukrainy 1917-1923 rr. T. 2. Niu-York, 1954. 512 s. [in Ukrainian].

Konovalets Ye. M. Prychynky do istorii ukrainskoi revoliutsii. Praha, 1928. 38 s. [in Ukrainian].

Laba V. Mytropolyt Andrei Sheptytskyi. Liublin, 1990. 63 s. [in Ukrainian].

Levytskyi K. A. Velykyi zryv. Niu-York, 1968. 151 s. [in Ukrainian].

Lototskyi O. H. Brat na brata. Volia. 1921. T. 2. S. 210-217. [in Ukrainian].

Lototskyi O. H. Znevazhena sprava. Tryzub. 1927. Ch. 12 (70). S. 6-11. [in Ukrainian].

Luzhnytskyi H. L. Ukrainska tserkva mizh Skhodom i Zakhodom: narys istorii Ukrainskoi Tserkvy.

Filadelfiia : Provydinnia, 1954. 723 s. [in Ukrainian].

Makukh I. I. Na narodnii sluzhbi. Detroit, 1958. 628 s. [in Ukrainian].

Mykytiuk D. Ukrainska Halytska Armiia. Vinnipeh, 1958. T. 1. 673 s. [in Ukrainian].

Mytropolyt Sheptytskyi - pokrovytel ukrainskoi kultury. Novyi Shliakh. 1944 r. Ch. 26. URL:

http://tsdazu.gov.ua/index.php/ua/online/47-all/1262-200218.html (data zvernennia: 15.09.2018). [in Ukrainian].

Nahaievskyi I. D. Spohady polovoho dukhovnyka. Toronto, 1985. 185 s. [in Ukrainian].

Nazaruk O. T. Rik na Velykii Ukraini. Viden, 1920. 344 s. [in Ukrainian].

Chyzh N. Koly poklykannia staie zhyttiam. Shliakh peremohy. № 31.3 serpnia 2005 r. (2669). URL:

http://tsdazu.gov.ua/index.php/ua/online/47-all/1262-200218.html (data zvernennia: 10.10.2018). [in Ukrainian].

Chyzhevskyi P. I. Osnovy ukrainskoi derzhavnosti. Volia. 1921. T. 2. S. 404-418. [in Ukrainian]. 
Ukrainian].

Shankovskyi L. P. Ukrainska Halytska Armiia: voienno-istorychna studiia. Vinnipeh, 1974. 396 s. [in

Skoropadskyi P. P. Spohady. Kinets 1917 - hruden 1918. Kyiv ; Filadelfiia, 1995. 493 s. [in Ukrainian]. Sokhotskyi I. Y. Shcho daly Hreko-Katolytska Tserkva ta yii dukhovenstvo Ukrainskomu Narodovi. Filadelfiia, 1953. 103 s. [in Ukrainian].

Vesniani dni 1917 r. Tryzub. 1927. Ch. 12 (70). S. 1-3. URL: http://diasporiana.org.ua/wpcontent/uploads/ books/10380/file.pdf (data zvernennia: 12.09.2018). [in Ukrainian].

Vynnychenko V. K. Vidrodzhennia natsii (Istoriia ukrainskoi revoliutsii, kinets 1917 r. - hruden 1919 r.) : v 3-kh chastynakh. Ch. 3. Kyiv ; Viden, 1920. 535 s. [in Ukrainian].

Yaroslavyn S. Vyzvolna borotba na zakhidno-ukrainskykh zemliakh 1918-1923 rr. Filadelfiia, 1956. $183 \mathrm{~s}$.

Надійшла до редакції 17 травня 2019 р. 